\title{
A New Windings Design of 24 Slot Capacitor-Start Capacitor-Run Induction Motor
}

\author{
Zuriman Anthony, Erhaneli Erhaneli \\ Department of Electrical Engineering, Institute of Technology Padang (Institut Teknologi Padang), Indonesia
}

\begin{tabular}{l}
\hline \hline Article Info \\
\hline Article history: \\
Received May 24, 2018 \\
Revised Jul 29, 2018 \\
Accepted Dec 11, 2018 \\
\hline
\end{tabular}

\section{Keyword:}

Input current

Power factor

Single-phase induction motor Three-phase induction motor Windings design

\begin{abstract}
The conventional method of a single phase induction motor windings design usually constructed the main and auxiliary windings in both slot. So, there was a complicated winding design if that compare to the three-phase induction motor. Because of that, this study was aimed to design a new windings design of a single phase induction motor that construction like a three-phase induction motor. This study was focused to design a 24 slot capacitor-start capacitor-run induction motor. The windings in the motor are divided in 3 group like a three-phase induction motor. The two windings act as a main windings and the other winding act as auxiliary winding. The current rating of the winding of the proposed single-phase induction motor was $2.74 \mathrm{~A}$. The performances of the proposed method were compared with the performances of a three-phase induction motor that had the same current rating. The motor used as a comparator was a three-phase induction of $380 / 220 \mathrm{~V}, 2.74 / 4.7 \mathrm{~A}, \mathrm{Y} / \Delta$, cage rotor, 4 poles, $1.5 \mathrm{HP}, 1400 \mathrm{RPM}, 50 \mathrm{~Hz}$. The result of this study showed that the proposed design of single phase induction motor could be operated with better performances than the threephase comparator induction motor's.
\end{abstract}

Copyright $\left({ }_{0} 2018\right.$ Institute of Advanced Engineering and Science. All rights reserved.

\section{Corresponding Author:}

Zuriman Anthony,

Department of Electrical Engineering,

Institute of Technology Padang (Institut Teknologi Padang),

JL. Gajah Mada Kandis Nanggalo Padang, West Sumatera, Indonesia.

Email: antoslah@gmail.com

\section{INTRODUCTION}

Induction motors are the electric motor that widely used in many sectors, especially in industrial and home application, because these motors are simple and robust construction. There are two types induction motors in application, three-phase and single-phase induction motors. The three-phase induction motors usually have a high power rating that supplied by a three-phase power system, but the single-phase induction motors are supplied by a single-phase system [1]. The single phase induction motors are the electric motor that produced in low power rating. The motors usually operated on single phase supply and widely used in household sector, such as washing machines, fans, etc. The motors have 2 windings, auxiliary and main winding that are placed within 90 degrees of electrical in construction [1]. The motors will operate with better performance when are giving the capacitor bank on the terminal circuit of the motors. The capacitor bank serves to produce the phase difference between the two motor windings (main and auxiliary windings) which aims to produce a large torque [1], [2]. The three phase induction motors have 3 identical windings are separated by 120 degrees of electricity. The number of turns of each winding per pole is equal, so that the motor can operate with a balanced current on each winding when the three phases balanced source are used to the motors [1], [2]. By using an equivalent circuit, the characteristics of the motors can be analyzed well [1], [3], [4]. The equivalent circuit of the motors can be used to predict the characteristics of the motor on various load condition. So the hazard condition of the motors can be predicted before the motors operated 
directly on the power system. There are several methods that have been developed to predict the motor characteristics well [3], [5]-[11]. By using these methods, the performance of the motors will be easily predicted and drawn for more in-depth analysis needs.

In the development of operating system, the three-phase induction motors had been operated on single phase power system [5], [7], [12]-[15]. The motors were operated on single phase power supply by using the capacitor bank installing to the terminal of the motor [5], [7], [12]-[15]. By this condition, the threephase induction motor operated like a single-phase induction motor, especially capacitor start-capacitor run induction motor. Some others modification operation system had developed by using a single phase inverter, pulse wide modulation (PWM) control technique, etc. [7], [12]-[18]. Anthony [5] has published a paper that discussed about a method with completed by an equivalent circuit for analyzing the three-phase induction motors while operating on a single-phase power system. The equivalent circuit was suitable for analyzing the motors with an accuracy above $90 \%$. The motor had 3 groups of windings with characteristics similar to a single-phase induction motor and could be operated with better performance and power factor close to unity. In other cases, the single phase induction motors usually have 2 windings, main and auxiliary windings that are installed in the slot on the motor. Therefore, by attention to above description can be shown that when a single-phase induction motor is designed with construction similar to a three-phase induction motor, of course the single phase induction motor will be operated with better performances and power factor close to unity. Therefore, this study is intended to design a single-phase induction motor with windings construction similar to that of a three-phase induction motor that had 24 slots of the windings. This study only focused in discussing about the output power, power factor and efficiency of the motor.

\section{CONVENSIONAL WINDING DESIGN OF SINGLE PHASE INDUCTION MOTOR}

Single-phase Induction motors are alternating current motor that widely used in many house applications. The motors usually operate on single-phase power system. The conventional single phase induction motors usually have 2 windings, the main and auxiliary windings. As specially for single-phase capacitor-start capacitor-run induction motor, the two windings usually used for starting and running. The motor usually use 2 capacitors in operating system, ie start capacitor and run capacitor. The capacitor connectors to the windings of the single phase induction motors are shown in Figure 1 and Figure 2 respectively. The conventional windings design in the 24 slots of the stator on the motor that is referred to Figure 1 is shown in Figure 3.

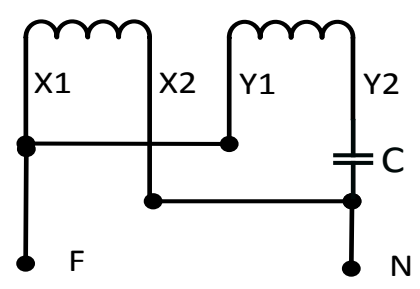

Figure 1. The capacitor connector to the windings of a single-phase capacitor run induction motor

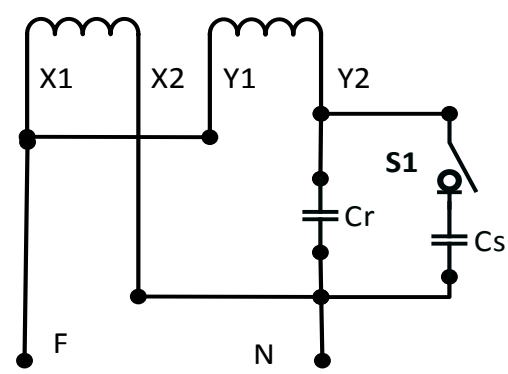

Figure 2. Windings design of a single-phase capacitor-start capacitor-run induction motor

From the Figure 1 and Figure 2 can be explained that the $\mathrm{X}$ to $\mathrm{X}$ ' and $\mathrm{Y}$ to $\mathrm{Y}$ ' are the main and auxiliary windings respectively. ' $\mathrm{C}$ ' in Figure 1 is the capacitor used for starting and running condition. ' $\mathrm{Cs}$ ' and ' $\mathrm{Cr}$ ' 
in Figure 2 are the capacitor start and capacitor run that are used for starting and running condition respectively. The letters ' $F$ ' and ' $N$ ' in Figure 1 and Figure 2 are the line power and the Neutral of the singlephase supply respectively.

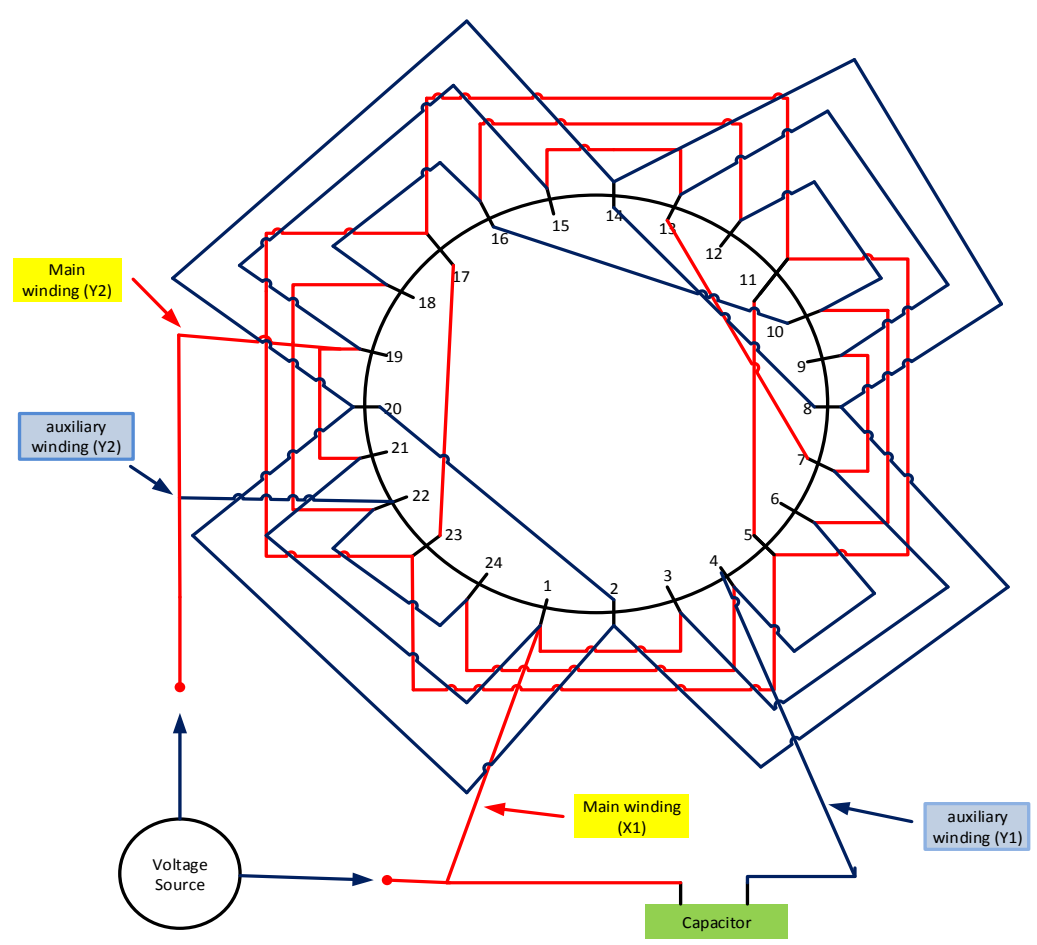

Figure 3. Conventional windings design in the 24 slots of the single phase induction motor

\section{RESEARCH METHOD}

This study aims to show a new windings design for single-phase induction motor, especially for capacitor-start capacitor-run induction motor. The winding design is similar to the three-phase induction motor's. To compare the capability of the proposed method, the performance of the proposed motor was compared to the performance of the three-phase induction motor that has the same current rating. The induction motors used as comparator for this study was a 3-phase induction motors with data 380/220V, 2.7/4.7A, Y/A, 4 poles, $1.5 \mathrm{HP}, 1400 \mathrm{RPM}, 50 \mathrm{~Hz}$. The motor of this proposed study has 3 windings (which we mark with as $\mathrm{X}, \mathrm{Y}$ and $\mathrm{Z}$ ) constructed in the stator, that are 2 windings (X, Y) act as an auxiliary windings and the other winding $(\mathrm{Z})$ acts as a main winding. There were two types of windings design in the proposed method. For the first method (A), all of the windings of the propose method were made the same size of $0,65 \mathrm{~mm}^{2}$ like an identical three phase induction motor. For the second method (B), the auxiliary winding $(\mathrm{X}, \mathrm{Y})$ was made bigger $15 \%$ than the main winding $(\mathrm{Z})$, where the main and the auxiliary windings were $0,65 \mathrm{~mm}^{2}$ and $0,75 \mathrm{~mm}^{2}$ respectively. The winding design of the proposed method is given in Figure 4 .

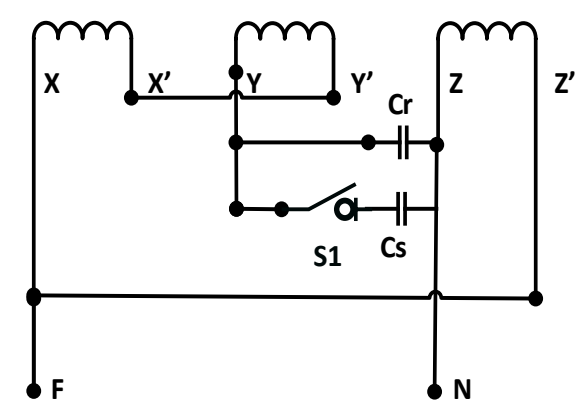

Figure 4. Single-phase induction motor on proposed model 
Letter ' $\mathrm{F}$ ' and ' $\mathrm{N}$ ' in Figure 4 are the phase and Neutral from a single-phase source system respectively. 'Cs' and ' $\mathrm{Cr}$ ' in Figure 4 are the start capacitor and run capacitor, respectively. 'S1' in Figure 4 is a switch (centrifugal switch) used to disconnect the capacitor start after the motor reach the run condition. Figure 5 gives a detail contraction of the windings design of the proposed method in the slot of the motor.

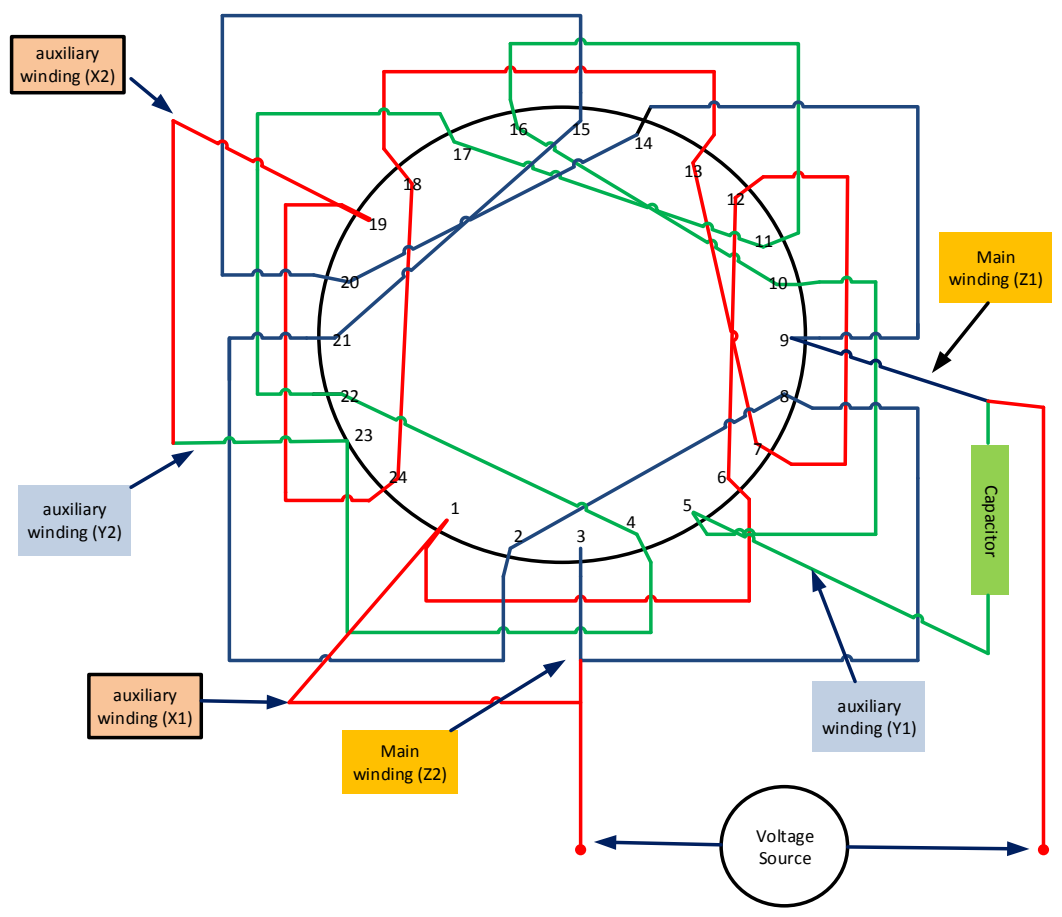

Figure 5. New windings design in the 24 slots of the proposed single phase induction motor

The capacitive reactance of the start capacitor $(\mathrm{Cs})$ and run capacitor $(\mathrm{Cr})$ as shown in Figure 4 can be calculated by using the formulas published by Anthony [14]. The step by step of calculating the 'Cs', 'Cr', line current $\left(I_{L}\right)$ and power factor $(P F)$ can be explained as follows.

$$
C s t=\frac{(0,1757) \cdot I_{N}}{(f) \cdot V_{L N}}(\text { Farad })
$$

The capacitive reactance of the run capacitor $(\mathrm{Cr})$ can be calculated as follows.

$$
C r=\frac{I_{N}}{(\omega) \cdot\left(2 V_{L N}\right)}=\frac{I_{N}}{(4) \cdot(\pi) \cdot(f) \cdot\left(V_{L N}\right)}(\text { Farad })
$$

Where:

$$
\begin{aligned}
& I_{N}=\text { nominal current of the winding of the motor }(\mathrm{A}) \\
& V_{L N}=\text { Line to neutral voltage }(\mathrm{V}) \\
& f=\text { Frequency of the source power system }(\mathrm{Hz})
\end{aligned}
$$

The capacitive reactance of the start capacitor (Cs) in the Figure 4, then can be calculated as follows.

$$
C s=C s t-C r(\text { Farad })
$$

The voltage on the run capacitor 'Vc' and the reactive power donated by the run capacitor (VARc) 
then can be calculated respectively as follows.

$$
\begin{aligned}
& V c=2 \cdot V_{L N} \\
& V A R c=\omega \cdot C r \cdot\left(2 \cdot V_{L N}\right)^{2}=4 \cdot \omega \cdot C r \cdot\left(V_{L N}\right)^{2}
\end{aligned}
$$

The apparent power $(\mathrm{S})$ and the line current $\left(I_{L}\right)$ of the proposed single-phase induction motor can be calculated by the following formula.

$$
S=V A R c
$$

Further, the line current $\left(I_{L}\right)$ enter into the motor can be calculated as follows.

$$
I_{L}=\frac{S}{V_{L N}}
$$

When a single-phase induction motor is operated with the nominal current shown in Equation (7), the motor will operate with a power factor close to unity. Therefore, the power factor $(P F)$ and power input (Pin) of the motor can be defined as follows.

$$
\begin{aligned}
& P F=\operatorname{Cos}(\varphi)=0,98 \\
& P \text { in }=S \cdot \operatorname{Cos}(\varphi)
\end{aligned}
$$

\section{RESULTS AND ANALYSIS}

The single-phase induction motor proposed was tested in the laboratory. The characteristics of the proposed motor then compared to the characteristics of the three-phase induction motor that had the same coil rating. From the result of this study can be explained the characteristic of the proposed method which is compared to a 3-phase induction motor as follows.

\subsection{Output Characteristic}

The output power characteristic of the motors is shown in Figure 6.

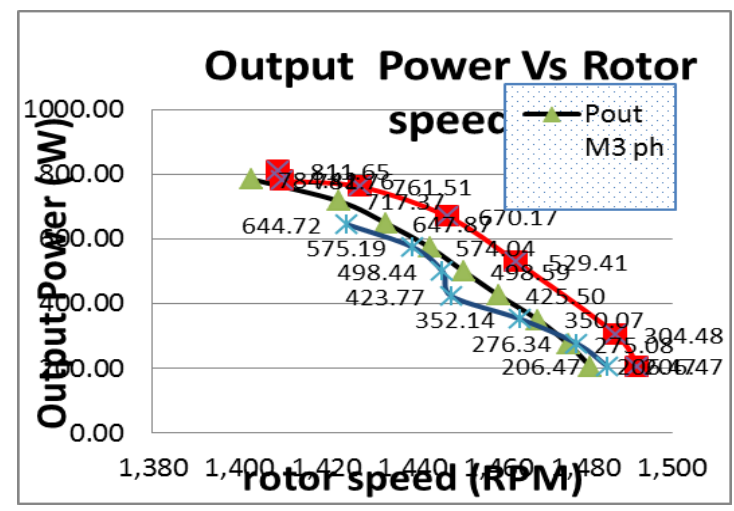

Figure 6. Output power characteristic of the motors

From the Figure 6 can be seen that the second method (Pout M1-ph B) of the proposed motor had better performance in power output than both of the first method (Pout M1-ph A) and the 3-phase induction motor (Pout M3 ph). This is because of the second method has auxiliary windings (X, Y) bigger $15 \%$ than the main windings. Of course, the torque developed in second method was slightly bigger than the first

A New Windings Design of 24 Slot Capacitor-Start Capacitor-Run Induction Motor (Zuriman Anthony) 
method. So that the second method of the proposed single-phase induction motor could be operated better or close to the three-phase power rating of the a comparator induction motor.

\subsubsection{Power factor characteristic}

The power factor characteristic of the motors is shown in Figure 7.

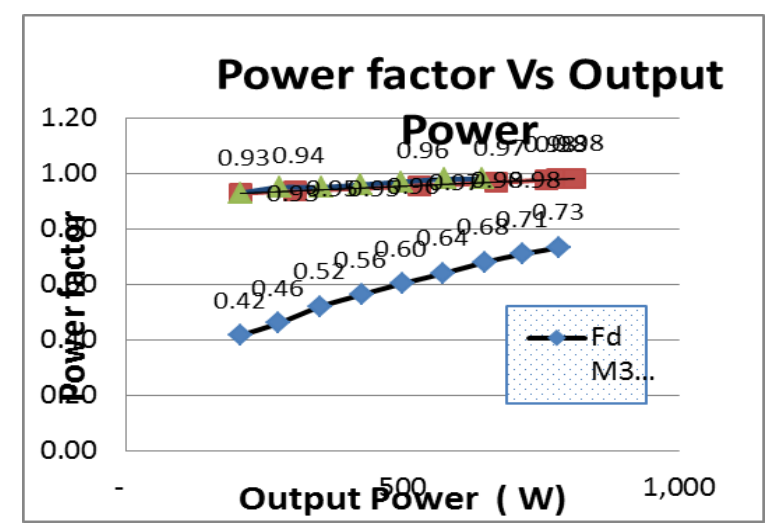

Figure 7. Power factor characteristic of the motors

From the Figure 7 can be seen that all the proposed method ('Fd M1-ph B' and 'Fd M1-ph A') had better performance in power factor than the 3-phase induction motor ( $\mathrm{Fd} \mathrm{M} 3 \mathrm{ph}$ ). The power factor of the proposed method always above 0.9 and then power factor reach 0.98 at full load conditions that was better than the three-phase induction motor's. This is because the capacitor used in the proposed method is set in Equation (2) to improve power factor to become close to unity.

\subsubsection{Efficiency characteristic}

The Effeciency characteristic of the motors is shown in Figure 8.

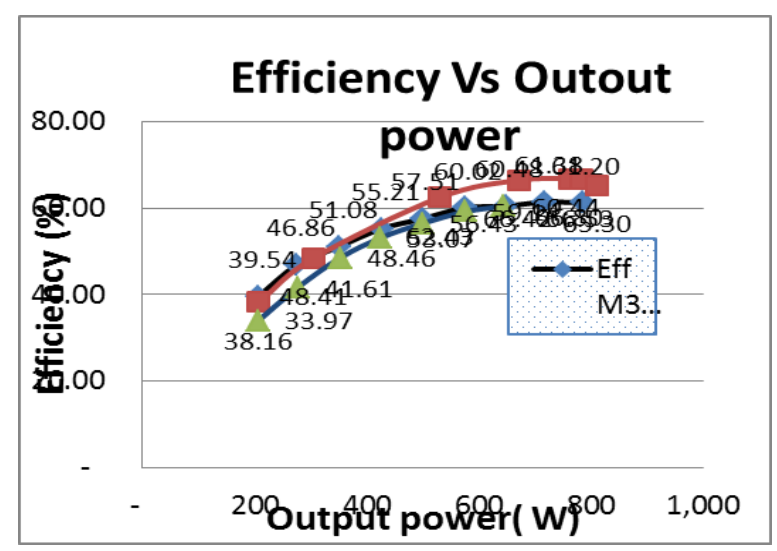

Figure 8. Efficiency characteristic of the motor

From the Figure 8 can be seen that the second method (Eff M1-ph B) of the proposed motor had better performance in efficiency than both of the first method (Eff M1-ph A) and the 3-phase induction motor (Eff M3 ph). That was because of the second method has auxiliary windings (X, Y) bigger $15 \%$ than the main windings. Of course, the torque developed in second method was slightly bigger than the first method. So that the second method of the proposed single-phase induction motor could be operated with an efficiency higher than both the first method and the 3-phase induction motor's.

If we compare all the maximum data of the motors, it can be seen that in Table 1.

From Table 1 it can be seen that the second method (B) of the proposed single phase induction 
motor design has better performance than the three phase induction motor's. If we validate all the equations of the proposed method to the experiment results, the data are given in Table 2.

Table 1. Motors Characteristics at full Load Conditions

\begin{tabular}{llrrr}
\hline & \multicolumn{1}{c}{ No } & & & \\
& & & & \\
& & 644.72 & 811.65 & 784.42 \\
1 & Output Power (W) & 1425 & 1409 & 1403 \\
2 & Rotor Speed (RPM) & 0.980 & 0.984 & 0.733 \\
3 & Power factor & 60.44 & 65.30 & 61.20 \\
4 & Efficiency (\%) & & \\
\hline
\end{tabular}

Table 2. Calculation Results Compared to the Experimental Results of the Second Method (B) at

\begin{tabular}{lrrr}
\multicolumn{4}{c}{ Voltage 221.6V } \\
\hline Indicators & $\begin{array}{c}\text { Experimental } \\
\text { results }\end{array}$ & $\begin{array}{c}\text { Calculation } \\
\text { results }\end{array}$ & Error (\%) \\
\hline $\mathrm{I}_{\mathrm{L}}$ (A) & 5.713 & 5.567 & 2.556 \\
Power Factor & 0.984 & 0.980 & 0.406 \\
Pin & 1243.000 & 1208.886 & 2.745 \\
\hline
\end{tabular}

Where:

Error $(\%)=$ percentage error of the calculation results when compared to the experimental results

From Table 2 can be seen that the formulas that have been given above show a good and accurate result if we compared to the experimental result. The formulas have high accuracy to calculate the line current (IL), power factor and power input (Pin) of the motor, because the error result only below $3 \%$. So, the method given in this research is very good to use for designing of single phase induction motor.

\section{CONCLUSION}

This study was focused to design a new windings construction of a single-phase induction motor especially for 'capacitor-start capacitor-run induction motor'. The windings design was like a three-phase induction motor's. The best design of the proposed single phase induction motor was to use auxiliary windings $15 \%$ bigger than the main windings. The proposed single phase induction motor could operate at three phase power motor rating with better performance. The formulas given in this study had high accuracy and good to use to predict the line current, power factor and power input of the proposed single phase induction motor.

\section{ACKNOWLEDGEMENTS}

We would like to thank very much to the team of the laboratory of electrical engineering of the 'Institute of Technology Padang (Institut Teknologi Padang)' whose helped us in research in the laboratory. We would also like to thank for 'Kopertis Wilayah X' and 'Directorate of Research and Community Service, Directorate General for Research and Development at the Ministry of Research, Technology and Higher Education' Republic of Indonesia whose helped fund this research in accordance with the research contract number 530/27.O10.4.2/PIN/2017.

\section{REFERENCES}

[1] P. C. Sen, Principles of Electrical Machines and Power Electronics, 2nd ed. New York: John Wiley \& Sons, 1996.

[2] S. J. Chapman, Elecrical Machinery Fundamentals, 4th ed. New York: McGraw-Hill, 2005.

[3] W. Gang and P. Sung-Won, "Improved Estimation of Induction Motor Circuit Parameters with Published Motor Performance Data", Green Technol. Conf. (GreenTech), 2014 Sixth Annu. IEEE, pp. 25-28, 2014.

[4] Z. Anthony, et al., "A New Equivalent Circuit of the three-phase Induction Motor (Case Studies: Current And Power Factor Of The Motor)", vol. 12, no. 23, pp. 6967-6974, 2017.

[5] Z. Anthony, "Equivalent Circuits for the M31D-ZA Motor "s Method (Case Studies : Currents and Power Factor of the motor)", IJETT, vol. 25, no. 1, pp. 49-52, 2015.

[6] G. A. Shanshurov, "A Mathematical Model of a Single-Phase Induction Motor with an Asymmetric Stator A New Windings Design of 24 Slot Capacitor-Start Capacitor-Run Induction Motor (Zuriman Anthony) 
Winding”, vol. 78, no. 9, pp. 467-473, 2007.

[7] Y. A. Al-turki and H. Al-umari, "Application of the Reference Frame Theory to the Dynamic Analysis of a ThreePhase Induction Motor fed from a Single-Phase Supply”, Elsevier, vol. 53, pp. 149-156, 2000.

[8] V. Ghial, et al., "Parameters Estimation of Permanent Split Capacitor Run Single Phase Induction Motor Using Computed Complex Voltage Ratio", IEEE Trans. Ind. Electron., no. c, pp. 1-10, 2013.

[9] R. Fiser, et al., "Induction Motor Parameters in Case of Rotor Electrical Asymmetry", Proc. - 2013 IEEE Work. Electr. Mach. Des. Control Diagnosis, WEMDCD 2013, pp. 271-278, 2013.

[10] M. Myers, et al., "Determination of the Parameters of Non-symmetric Induction Machines", Conf. Proc. - IEEE Appl. Power Electron. Conf. Expo. - APEC, no. 1, pp. 1028-1033, 2011.

[11] S. Enache, et al., "Method and Device of Synchronization for Determination of Squirrel Cage Asynchronous Motors Parameters", 2013 - 8th Int. Symp. Adv. Top. Electr. Eng. ATEE 2013, 2013.

[12] N. A. Ahmed, "Three-phase Induction Motor Operating from single-phase Supply with an Electronically Controlled Capacitor", Electr. Power Syst. Res., vol. 73, no. 2, pp. 121-128, 2005.

[13] Z. Anthony, "A Simple Method for Operating the Delta Connection Standard of the 3-phase Induction Motor on Single Phase Supply", IJETT, vol. 15, no. 9, pp. 444-447, 2014.

[14] Z. Anthony, "A Simple Method for Operating the Three-Phase Induction Motor on Single Phase Supply (For Wye Connection Standard)", IJETT, vol. 5, no. 1, pp. 13-16, 2013.

[15] Z. Anthony, "Analyzing Characteristics of the Sheda "s Method for Operating the 3-phase induction Motor on Single Phase Supply (Case studies : output power and efficiency of the motor)", IJETT, vol. 33, no. 4, pp. 175-179, 2016.

[16] W. Yaw-juen, et al., "Balancing a Three-Phase Induction Motor Supplied from a Single-Phase Source with Two SVCs", no. 3, 2017.

[17] A. K. Adapa and V. John, "Active Phase-Converter for Operation of Three-Phase Induction Motors on SinglePhase Grid", 2016.

[18] P. Brzezlrekl and J, Pillay, "Induktion Motor Performance Fed from Single to Three Phase Converter", IEEE, 1990.

\section{BIOGRAPHIES OF AUTHORS}

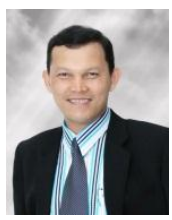

Zuriman Anthony is a lecturer in the Institute of Technology Padang (Institut Teknolgi Padang) on Department of Electrical Engineering. His research's interest in Electrical Machines and Control. He received an M. Eng from Gadjah Mada University, Yogyakarta, Indonesia in 2002. He always active in many researches about the induction motors

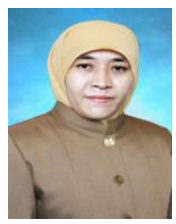

Erhaneli is a lecturer in the Institute of Technology Padang (Institut Teknolgi Padang) on Department of Electrical Engineering. Her research's interest in Electrical Machines and Power Distribution. She received an M. Eng from Gadjah Mada University, Yogyakarta, Indonesia in 2003. She always active in many researches about the induction motors and power system distribution. 